Sains Malaysiana 50(12)(2021): 3481-3491

http://doi.org/10.17576/jsm-2021-5012-02

\title{
Carbon-Ion Beam Radiosensitivity Study and Biological Responses of High- Yielding Rice Line, MR219-PL-5
}

(Kajian Radiopekaan Sinar Ion Karbon dan Tindak Balas Biologi Titisan Padi Berhasil Tinggi, MR219-PL-5)

\author{
Asrapil Waitul Fifika, Asmuni Mohd Ikmal, Ahmad Faiz, Hasan Nor'Aishah, Harun Abdul Rahim, \\ HUSSEIN SOBRI \& ABD AZIZ SHAMSUdIN NORAZIYAH*
}

\begin{abstract}
The carbon ion-beam has emerged as a novel physical mutagen for creating genetic variability and crop improvement. In this study, seeds of a high-yielding pyramided rice line MR219-PL-5 were exposed to carbon ion beam irradiation at 10, 20, 40, 60, 80, and 100 Gy. The radiosensitivity test was conducted to determine the optimum dose of carbon ion beam irradiation based on the lethal dose $50 \%\left(L D_{50}\right)$ using Sandwich Blotter Technique. The biological responses of carbon-ion beam irradiation were also observed in other characteristics such as germination rate (GeR), survival rate (SR), growth rate (GRoR), shoot length (SL), root length (RL), seedling height (SH), days to flowering (DTF), fertility rate (FR) and thousand-grains weight (TGW). Based on the polynomial curve of SR graph, the lethal dose $50 \%$ (LD 50$)$ value was $86.12 \mathrm{~Gy}$. However, the optimum dose range of carbon ion-beam irradiation was between 40 and $60 \mathrm{~Gy}$ as these two doses recorded the highest SR, 63 and 67\%, respectively. Furthermore, the shoulder dose in this study was 60 Gy since SR decreased significantly at higher doses. $M_{1}$ individuals irradiated at 40 and 60 Gy had the best biological responses where significant differences were found for SR, SL, RL, GRoR, SH, DTF and FR at these two doses compared to the other doses. Further studies on $M_{2}$ and $M_{3}$ populations could help to identify potential individuals as well as to understand the inheritance of each trait of interest from one generation to the next.
\end{abstract}

Keywords: Biological response; carbon-ion beam; mutation breeding; optimum dose; rice

\section{ABSTRAK}

Sinar ion karbon telah berkembang sebagai mutagen fizikal baru untuk mewujudkan kepelbagaian genetik dan penambahbaikan tanaman. Dalam kajian ini, biji benih titisan piramid padi MR219-PL-5 telah didedahkan kepada pancaran sinar ion karbon pada 10, 20, 40, 60, 80 dan 100 Gy. Ujian radiopekaan telah dijalankan untuk mengenal pasti dos optimum pancaran sinar ion karbon berdasarkan dos maut 50\% (LD 5 ) menggunakan Teknik Sandwich Blotter. Tindak balas biologi pancaran sinar karbon ion juga diperhatikan bagi ciri-ciri seperti kadar percambahan (GeR), kadar kemandirian (SR), kadar pertumbuhan (GRoR), panjang pucuk (SL), panjang akar (RL), tinggi anak pokok (SH), bilangan hari berbunga (DTF), kadar kesuburan (FR) dan berat seribu-bijian (TGW). Berdasarkan graf polinomial $S R$, nilai dos maut $50 \%\left(L D_{50}\right)$ adalah pada 86.12 Gy. Walau bagaimanapun, julat dos optimum sinaran pancaran ion karbon dipilih pada dos antara 40 dan 60 Gy kerana kedua-dua dos ini masing-masing mencatatkan SR tertinggi, 63 dan 67\%. Selanjutnya, dos bahu dalam kajian ini adalah 60 Gy kerana SR menurun dengan ketara pada dos yang lebih tinggi. Sejajar dengan hasil $L D_{50}$, individu $M_{1}$ yang disinari pada 40 dan 60 Gy mempunyai tindak balas biologi terbaik berdasarkan tindak balas biologi pada keturunan $M_{1}$ dengan perbezaan yang signifikan didapati untuk $S R, S L, R L, G R o R$, SH, DTF dan FR pada kedua-dua dos ini berbanding dengan dos-dos yang lain. Kajian lanjutan tentang populasi $M_{2}$ dan $M_{3}$ dapat membantu mengenal pasti individu mutan berpotensi dan memahami keterwarisan setiap ciri yang diingini daripada satu generasi ke generasi berikutnya.

Kata kunci: Alur ion karbon; biak baka mutasi; dos optimum; padi; tindak balas biologi

\section{INTRODUCTION}

Mutation breeding is widely used to enhance plant varieties by changing their genetic information in a relatively shorter period compared to conventional breeding (Yasmine et al. 2019). Mutation means the hereditary changes that occur naturally and suddenly, which are not caused by recombination and segregation (Ulukapi \& Nasircilar 
2018). Recently, energetic heavy ion-beams have been used to generate mutants in plants because they induce mutations with high frequency at a relatively lower dose especially at which virtually all plants survive and they induce a broad spectrum of phenotypes without affecting other plant characteristics or severe growth inhibition (Abe et al. 2007). The investigation on the effectiveness of ion-beam irradiation for mutation induction in tobacco embryos during fertilization without any damage to other plant tissues led to the widespread use of this technology (Abe et al. 2007). It has been shown that ion-beam irradiation has many outstanding advantages including lower damage rate, higher mutation rate and wider novel mutational spectrum as it is generated by speeding up atomic ions using particle accelerators (Sjahril et al. 2018). In Japan, the application of ion-beam technology in mutation induction has started for more than 20 years. Since that, many mutant varieties including rice with high yield, broader disease resistance, shorter growth period but higher grain quality have been introduced (Tanaka et al. 2010; Yamaguchi 2013).

In general, the ion-beam has much higher linear energy transfer (LET) than other physical mutagens. This LET is an important key to understand the effectiveness of selected radiation to induce mutation on biological organisms. It can be defined as the energy per unit track length, and it gives a measure for the density of energy dissipated by particles along with a given track in the study of seed embryo (Gregory 1972). The biological effects of ion-beams have also been investigated and observed to show a high relative biological effectiveness (RBE) in lethality, mutation and also to transfer high energy to the target compared to low LET radiation such as Gamma-rays, X-rays and electrons (Tanaka et al. 2010). Since then, carbon ion beams have been used in rice breeding programs, and several useful mutant lines have been created, including low cadmium rice, UVB-tolerant mutants, and extremely late heading mutants (Zheng et al. 2020).

Radiosensitivity test is a relative measure that indicates the number of recognizable effects of radiation on the irradiated objects (Abe et al. 2007). The function of radiosensitivity test is to determine the optimum dose for irradiation by calculating the lethal dose $\left(\mathrm{LD}_{50}\right)$ and shoulder dose which usually create maximum variability with minimum number of undesirable mutants (Tanaka et al. 2010). Shoulder dose is referred to the dose that does not affect survival significantly, and it can be concluded as a good criteria to assess the effect of radiation without influencing by their genetic background (Yamaguchi et al.
2009). To determine optimum irradiation doses, it is very useful to understand the general radiation sensitivities of plants. Basically, the radiation sensitivity of living cells depends on the genome size and the nuclear contents per cell. According to Gregory (1972), increase in genome size of plant species will also increase the sensitivity of the plant against radiation. Radiation sensitivities of plants differ greatly among not only plant species, but also plant materials (seeds, plantlets and tissues) or organs, DNA and water content. Cells in synthesis phase (phase in which DNA replication occur) of the cell cycle are the most sensitive to radiation because at this stage, the DNA content increases and the chromosomal DNA molecules are unpacked, leading to a cell status that is readily attacked by radiation and the secondary radical products. Radicals such as hydroxyl radicals are the major cause of DNA damage. It is well known that these radicals are generated by reactions between water and radiation. Therefore, plant materials such as dry seeds, in which the water content is very low, tend to show high resistance to radiations (Magori et al. 2010). Many factors influence the effectiveness of ion beam irradiation in inducing mutation, and the effects of this mutagen are also assumed to be different for each rice species and genotype (Gregory 1972). This is supported by Tanaka et al. (2010), who concluded that radiation sensitivity is strongly dependent not only on sub-species (such as indica or japonica in rice) but also for specific genotype.

To increase the success of mutation breeding through ion beam irradiation, the selection of parental line (wild type) is a critical step in order to develop superior mutant lines. MR219-PL-5 was developed by introgression of three drought yield QTLs ( $q D T Y s)$ into Malaysia megavariety, MR219 using marker-assisted QTL pyramiding technique (Shamsudin et al. 2016). This pyramided line comes with desirable traits such as high yield, intermediate tolerance to drought and having short maturity period compared to its recipient parent, mega-variety MR219 which is highly sensitive to drought (Ikmal et al. 2020, 2019, 2018). It is expected that this carbon ion beam may give rise to superior MR219-PL-5 mutants with tolerance to submergence and resistance to diseases other than higher yield and tolerance to drought. The current study was conducted as a preliminary study to determine the optimum dose and the biological responses of ion-beam irradiation on dry rice seeds of a high-yielding pyramided line, MR219-PL-5.

MATERIALS AND METHODS 


\section{CARBON ION BEAM IRRADIATION METHOD}

The radiation was conducted at Japan Atomic Energy Research Institute (JAERI), Tokyo, Japan. Takasaki Ion Accelerators for Advanced Radiation Application (TIARA) was used as an electron cyclotron resonance heavy-ion source to produce vertical ion beam of carbonion $(12 \mathrm{C}+6 ; 320 \mathrm{MeV})$, and the ion beam was accelerated by an Azimuthally Varying Field (AVF) cyclotron (Hidema et al. 2003). The seed coat of MR219-PL-5 was removed as ion beam cannot penetrate the seed coat making the ray unable to reach the embryo inside. Hundred seeds of MR219-PL-5 were irradiated for 3 min under atmospheric pressure at 10, 20, 40, 60, 80 and $100 \mathrm{~Gy}$. The nonirradiated seeds were used as control ( $0 \mathrm{~Gy})$.

\section{SANDWICH BLOTTER TECHNIQUE}

Radiosensitivity test was performed to evaluate lethal doses and determine optimum doses of carbon ion beam irradiation for MR219-PL-5. This experiment was carried out at a molecular laboratory of Agrobiology and
Biosciences Division, Malaysia Nuclear Agency, Kajang, Selangor. Fifty seeds from each dose were placed in separate Petri dishes. Seeds were treated with fungicide by pouring the fungicide solution into each Petri dish. All Petri dishes were arranged in a tray and kept at the growth chamber for $24 \mathrm{~h}$. After $24 \mathrm{~h}$, the soaked seeds were rinsed with distilled water. The Sandwich Blotter experiment as described by Myhill and Konzak (1967) was carried out using completely randomized design (CRD) with three replications. Ten soaked seeds of each dose per replication were placed on the wet blotter paper with the embryo facing downward. Then, the sandwich blotter was placed on the rack and the rack was transferred into a plastic tray. Three-quarter of the plastic tray was filled with water and the plastic trays were kept in a germination chamber to maintain high humidity (Figure 1). After 14 days, the rice seedlings were removed from the blotter paper and transplanted into pots containing wet soil. 'Rice Check' published by Department of Agriculture Malaysia (2018) was followed for the cultural management of the rice plants.

\section{DATA COLLECTION AND ANALYSIS}
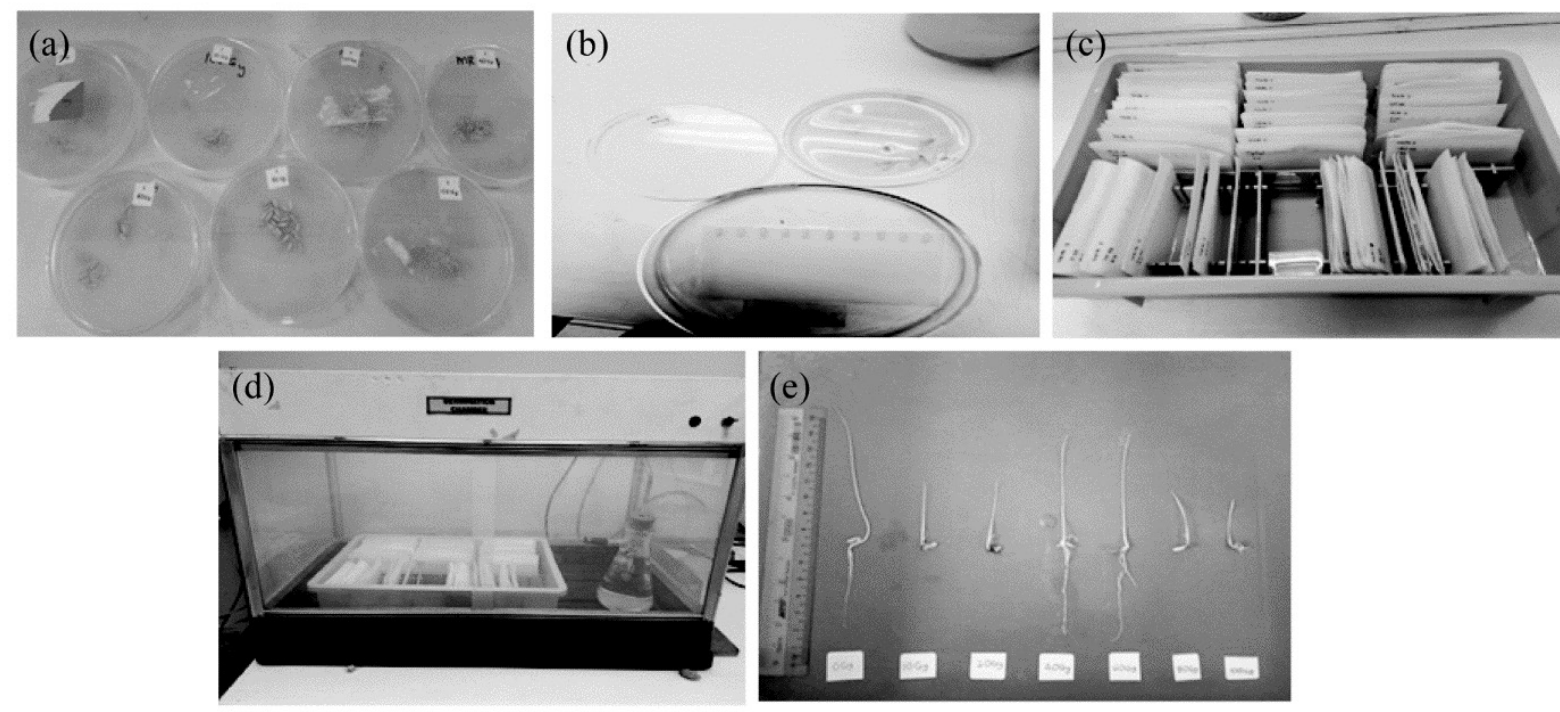

FIGURE 1. Sandwich Blotter technique. (a) Seed germination, (b) Seed arrangement on sandwich paper, (c) Sandwich paper in the water filled tray, (d) Sandwich blotter was kept in the germination chamber, and (e) The seedling height was calculated among all the doses

Germination rate $(\mathrm{GeR})$ was obtained three days after germination while survival rate (SR) was recorded seven days after germination. Shoot length (SL) and root length (RL) in $\mathrm{cm}$ were also measured seven days after transplanting. Seedling height $(\mathrm{SH})$ in $\mathrm{cm}$ was taken 14 days after transplanting, while relative growth rate (GRoR) was taken 30 days after transplanting. Days to flowering (DTF) were recorded when $50 \%$ of the plants 
of each dose were flowering. The thousand-grain weight (TGW) and fertility rate (FR) were obtained after harvest. Harvested grains were dried, weighed and adjusted to $14 \%$ moisture content before TGW and FR data were taken.

The results obtained from the radiosensitivity test and biological responses of the plant samples were subjected to a one-way analysis of variance (ANOVA) and Tukey's honestly significant difference (HSD) test at $p<0.05$ using MINITAB software. The base and corrplot packages in $\mathrm{R}$ were used to compute the correlation values and produce the graphical correlation matrix, respectively. The lethal and shoulder doses for irradiation of carbon ion-beams were determined by using the polynomial curve of survival graph using GraphPad Prism 8. The following formulas were used to compute GeR, SR and GRoR and FR:

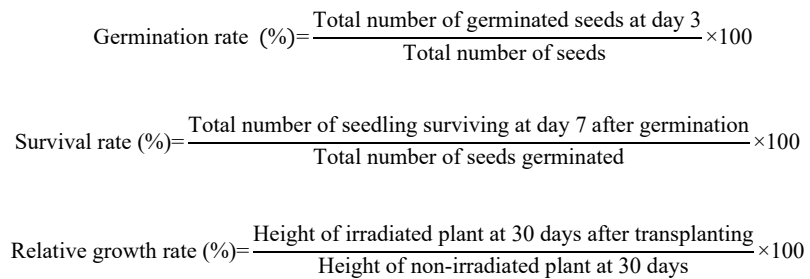

Fertility rate $(\%)=\frac{\text { Total number of filled spikelets per panicle }}{\text { Total number of spikelet perpanicle }} \times 100$

\section{DETERMINATION OF OPTIMUM DOSE RANGE}

In this study, the SR for control was $90 \%$, and not $100 \%$ as expected due to fungal infection during the germination as the control seeds were not treated with fungicides. Therefore, $\mathrm{LD}_{50}$ value was calculated based on $90 \% \mathrm{SR}$ of the control treatment which is $45 \%$. Based on the polynomial curve with $\mathrm{R}^{2}$ value $77.81 \%$ and equation $0.8271-0.02498 \mathrm{~Gy}+0.000598 \mathrm{~Gy}^{2}-0.000004 \mathrm{~Gy}^{3}$, the SR of $45 \%$ was recorded when the carbon ion-beam dose was 86.12 Gy (Figure 2). The shoulder dose also showed that the SR was gradually decreased after 60 Gy as SR decreased significantly at $80(43 \%)$ and 100 Gy $(26 \%)$ (Figure 2). Therefore, the optimum dose range of carbon ion-beam of MR219-PL-5 was assumed between 40 and 60 Gy. However, Yamaguchi (2011) reported that the optimum dose of carbon ion beam for 'Hitomebore' rice was at $73 \mathrm{~Gy}$, slightly higher that result obtained in this study.

EFFECT OF MUTAGEN ON GERMINATION AND SURVIVAL

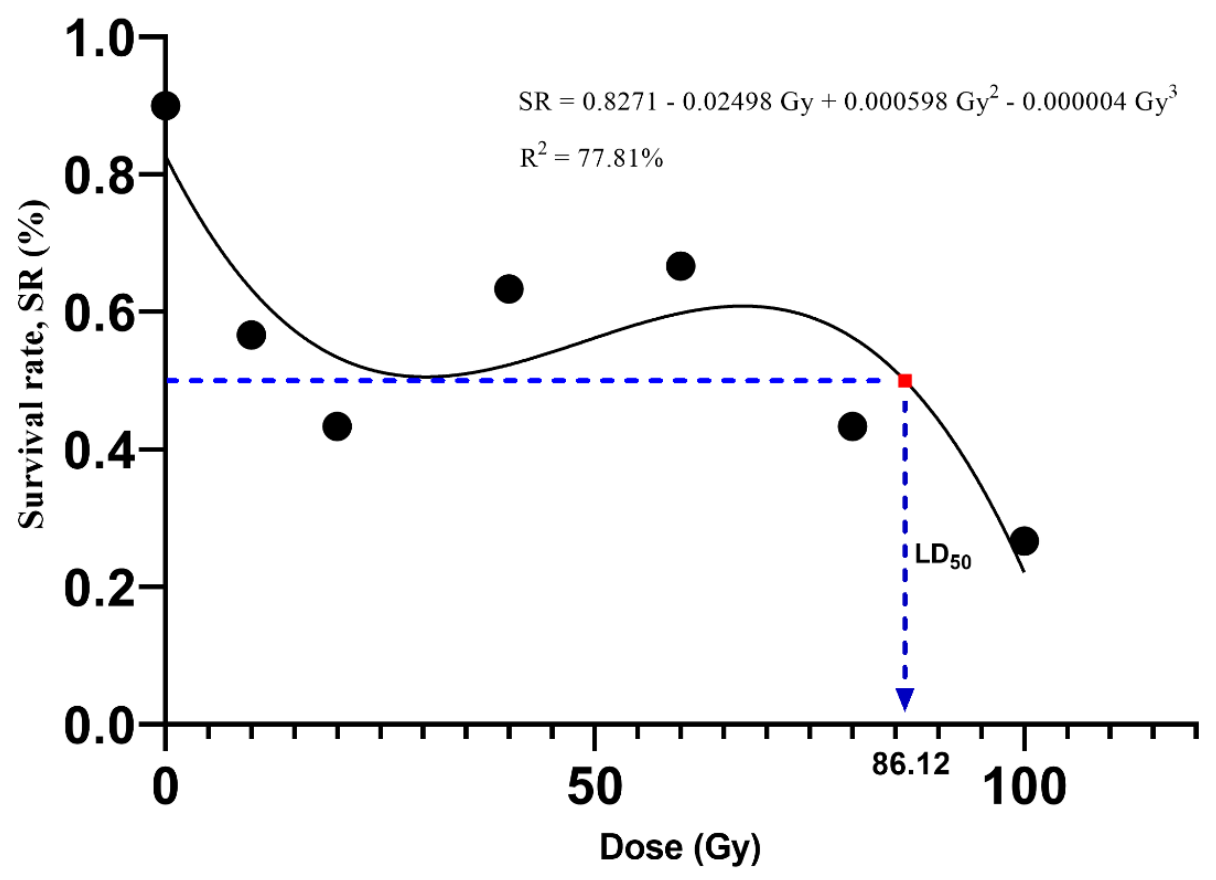

FIGURE 2. Polynomial curve of survival graph from GraphPad Prism 8 to determine the lethal dose $\left(\mathrm{LD}_{50}\right)$ 
RATE

Generally, GeR and SR showed almost the same trends when their mean values decreased at 10 and $20 \mathrm{~Gy}$, rose at 40 and $60 \mathrm{~Gy}$, before decreased again at 80 and $100 \mathrm{~Gy}$ (Figure 3). As expected, the control treatment recorded the highest mean values for both GeR and SR as the seeds were not affected by carbon ion beam irradiation (Figure 3). However, significant difference $(p<0.001)$ on dose was only observed for SR but not for GeR (Table 1). Based on Tukey's HSD test, significant differences in SR were observed between control and other treatments with the highest and the lowest values of SR at 60 and 100 Gy, respectively (Figure 3). However, Tanaka et al. (2010) reported that rice variety Ashal, SR was significantly reduced at 60 Gy onwards. As compared to control dose, GeR and SR of the other doses were lower, which probably due to embryonic tissue damage or seed dormancy effects (Mamun et al. 2013). Indirectly, the metabolic variation of free fundamental growth and DNA injury of isolated cells may influence the negative impact of radiation on plants (Jones et al. 2004). Separation of the cells is known to be the most difficult treatment process

(a)

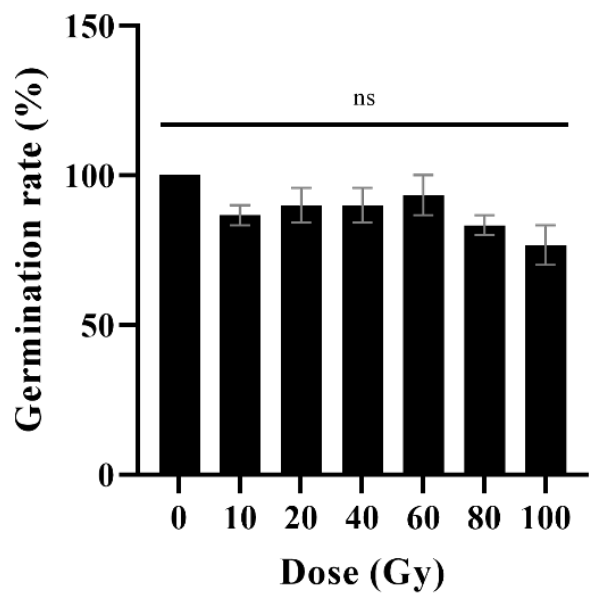

in connection with reduced seedling growth (VazquezTello et al. 2005).

Thus, the inhibition patterns of plants could be different from one variety to another. The most sensitive parameter to irradiation should take account of growth inhibition found in irradiated plantlets (Vazquez-Tello et al. 2005). Due to the G2/M phase during somatic cell division, higher doses of irradiation can cause growth inhibition or genome damage (Preuss \& Britt 2003) as shown in 80 and 100 Gy in this study. The optimal ionizing dose on plants that accelerating cell proliferation, stimulating germination and growth, improving stress tolerance, or even increasing production can be attributed to the hormetic effects (Kim et al. 2004). Carbon partitioning is altered by increasing the radiation dose because of the damage to radiosensitive cells that are responsible for the transport of carbohydrates in the phloem. Growth reduction in $\mathrm{M}_{1}$ progenies caused by the physical damage of the mutagen should be enough to get a probability of obtaining high frequencies of useful mutations in the $M_{2}$ generation (Gowthami et al. 2017).

\section{EFFECT OF CARBON ION BEAM IRRADIATION ON}

(b)

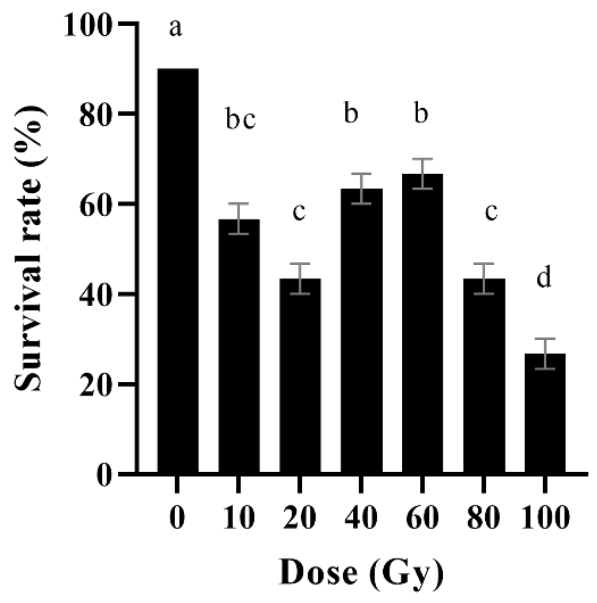

FIGURE 3. Effect of irradiation dose (Gy) to germination rate at day 3 (a) and survival rate at day 7 after germination (b)

\section{GROWTH RATE AND SEEDLINGS SHOOT AND ROOT LENGTHS}

The GRoR, SL, RL, and SH of irradiated rice plants were also observed to investigate the biological response of MR219-PL-5 towards different doses of carbon ion beam irradiation. These traits showed almost a similar pattern where their mean values decreased from 0 to $20 \mathrm{~Gy}$ and rose at 40 and 60 Gy before decreasing again at 80 and 100 Gy (Figure 4). As expected, the control dose recorded the highest mean values while the highest dose (100 Gy) 
recorded the lowest mean values for all the traits except SL (Figure 4). Interestingly, no significant difference was found between control and the optimum doses, 40 and 60 Gy treatments, for all the traits studied based on Tukey's HSD test (Figure 4).

Seedling height is often used as an indicator to assess the environmental effect of development or treatment (Saweho et al. 2019). As reported by Gowthami et al. (2017), after treatment with gamma radiation and electron beam, the SL of genotypes ADT-37 and ADT(R) 45 followed a linear relationship between dose increase and SL reduction. The SL increased again at 100 Gy from 2.33 to $3.06 \mathrm{~cm}$. The same trends were also reported by Hussien et al. (2020) where shoot length of Pongsu Seribu 2 increased again at 100 Gy after 80 Gy and dropped at 120 Gy.

Similarly, a reduction in the RL exposed to 20, 40, 60, 80,100 and 120 Gy of ion beam was also observed by Ling et al. (2013). In a study by Tanaka et al. (2002), in which the root apical tissues of Arabidopsis were irradiated with $220 \mathrm{MeV}$ carbon-ion beam, it was found that the vertical root elongation showed a slight increase of up to about 10 Gy, followed by an exponential decrease of up to 75 Gy and significantly suppressed at $100 \mathrm{~Gy}$ of carbon ion beam irradiation. Such findings were close to the results of this study, which showed improved rooting capacity at low doses of carbon-ion beam irradiation followed by a steady decrease in the root duration of the carbon-ion beam. Kalimullah et al. (2003) observed that the elongation of rice seedling's root extracted from $1 \mathrm{H}$ of heavy ion treated seeds was approximately $17 \%$ lower than that of control plants. The irradiated roots showed fixed growth. This result indicated that irradiation has an effect on the growth of roots. Damage and inactivation of the endogenic auxin balance due to irradiation may have caused the decrease in rooting ability of the treated plants (Khadimi et al. 2016).

The SH is commonly used as an index for the (a)

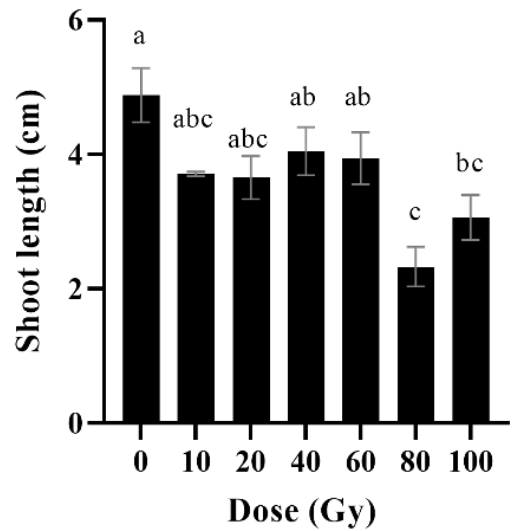

(c)

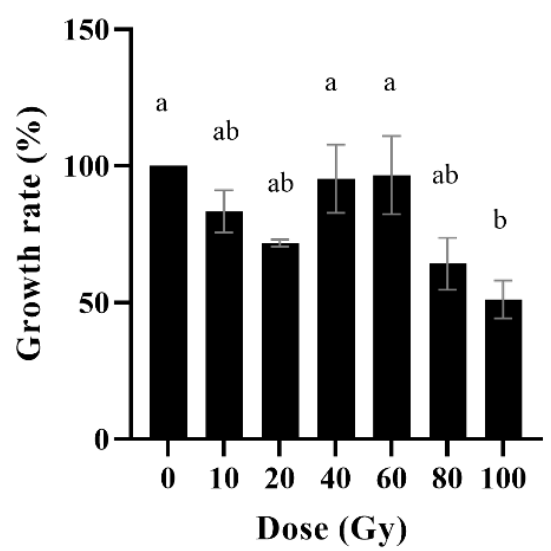

(b)

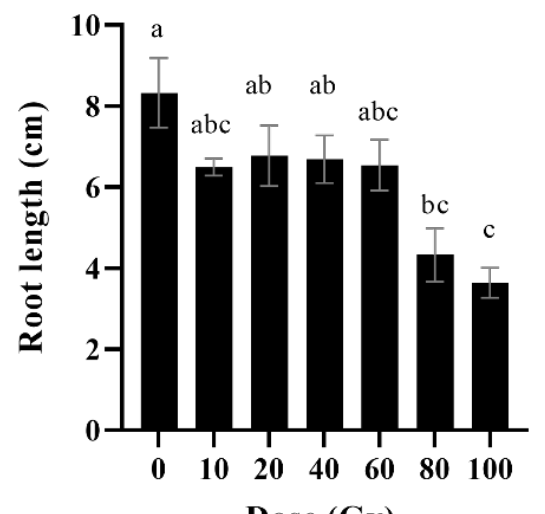

(d)

Dose (Gy)

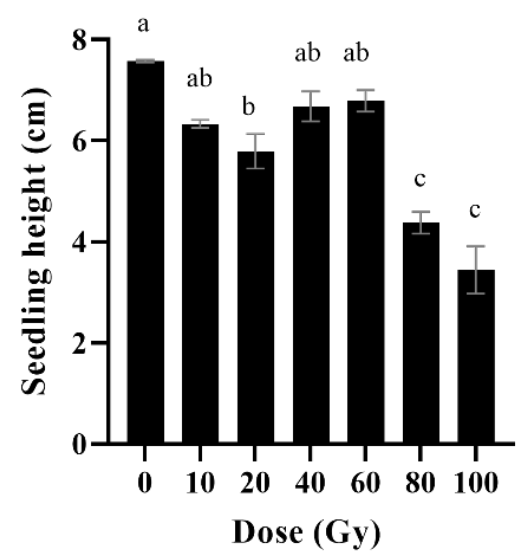

FIGURE 4. Effect of irradiation dose (Gy) to shoot length after 14 days of transplanting (a), root length after 14 days of transplanting (b), growth rate after 14 days of transplanting (c) and seedling height after 14 days of transplanting (d) 
biological effects of the various physical mutagens of $\mathrm{M}_{1}$. Significant differences $(p<0.05)$ in SH between nonirradiated control and plants irradiated at 20,80 and $100 \mathrm{~Gy}$ were also observed in this study (Figure 4(d)). However, all the seedlings showed a slight reduction in their height as compared to the control samples. The present study showed that there was inhibited growth in terms of GRoR and $\mathrm{SH}$ as the dose of carbon-ion beam increased except for optimum doses (40 and 60 Gy) (Figure 4(c))-4(d)). A similar result was obtained by Ling et al. (2013), who also observed the reduction of height in MR219 plants irradiated at high doses of carbon-ion beam. The negative impact of radiation on plants can be mediated indirectly by metabolism, free radical formation and by DNA damage to the deeply divided cells (Jones et al. 2004). The radiation sensitivities of plants also differ greatly among species (Magori et al. 2010).

\section{EFFECT OF CARBON ION BEAM IRRADIATION ON THE MORPHO-AGRONOMICAL TRAITS}

Significant differences between doses were witnessed in DTF $(p<0.05)$ and FR $(p<0.001)$ but not in TGW (Table 1). Even though the progenies from the exposure to 40 and 60 Gy carbon ion beam irradiation flowered earlier compared to the other treatments, no significant differences in DTF was observed between these two doses and the other treatments except for 80 Gy (Figure 5(a)). Mamun et al. (2013) also reported that $M_{2}$ progenies derived from 40 and 200 Gy doses of carbon ion beams flowered and matured in 85 and 110 days after sowing, which were much earlier than their parental line Ashfal that flowered and matured at 122 and 152 days after sowing in field condition. Early flowering suggests a shorter life cycle, and it is considered to be a good trait for the development of rice. Early maturing varieties are beneficial in areas with limited rainfall periods because they grow faster during the vegetative stage, and thus are more competitive with weeds. They minimize weed control costs and use less water (Oladosu et al. 2014). The TGW has no significant difference (Figure 5(b)), and the results were kept decreasing from 60 to $100 \mathrm{~Gy}$ as reported by Zheng et al. (2020), the values decreased as the dose increased.

Significant differences in FR were observed between the control and all the treatments except for the two optimum doses, 40 and 60 Gy based on Tukey's HSD test (Figure 5(c)). The mean values of FR were the highest at $0 \mathrm{~Gy}(82.13 \%)$, decreased at 10 and $20 \mathrm{~Gy}$, rose at 40 and $60 \mathrm{~Gy}$, and decreased again at 80 and $100 \mathrm{~Gy}$ (Figure 5(c)). As expected, 100 Gy recorded the lowest mean value $(49.57 \%$ ) (Figure $5(\mathrm{c})$ ). As reported by Luo et al. (2013), the FR declined as the dose increased up to 120 Gy except for $100 \mathrm{~Gy}$. The same observation was also observed by Ibrahim et al. (2013), where the highest FT was recorded at $80 \mathrm{~Gy}$. Hidema et al. (2003) reported that the FR significantly decreased by carbon-ion irradiation dose at doses at about $80 \mathrm{~Gy}$. The same pattern was observed by Hussien et al. (2020) where FR was the highest at 60 Gy and it declined as the dose increased. Fertility rate (FR) or rice grain filling mainly depends upon temperature, timely application of fertilizer, water level, time of watering and the tillering behaviour, and the tillering behaviour is the most important because late formed tillers fail to produce filled grains (Yasmine et al. 2019).

Grain yield is also closely correlated with solar radiation during the ripening period (Tanaka et al. 1966). Radiation-use efficiency (RUE) is defined as the efficiency of the use of intercepted radiation for production of biomass by crops, and it is considered to be the only remaining major potential for improving yields (Long et al. 2006). The decrease in grain fertility with an increase in dose was also observed by Awan and Bari (1979). The reduction in rice seed fertility after irradiation is considered due to the chromosomal aberrations (Gowthami et al. 2017). Based on FR, the mutation frequency induced by ion beams equaled or exceeded that induced by gamma rays. Thus, the ion beam also appears to efficiently induce mutantion with less radiation damage (Yamaguchi et al. 2009).

TABLE 1. Summaries of analyses of variance (mean squares)

of all the traits of the six carbon ion beam doses

\begin{tabular}{ccccccccccc}
\hline SOV & DF & GeR & SR & SL & LR & GRoR & SH & DTF & FR & TGW \\
\hline Dose & 6 & $165.08 \mathrm{~ns}$ & $1252.38 * * *$ & $1.93 * *$ & $7.66 * *$ & $1036.90 *$ & $6.37 * * *$ & $20.97 *$ & $461.03 * * *$ & $14.56 \mathrm{~ns}$ \\
Error & 4 & 76.19 & 2857 & 0.32 & 1.14 & 240.5 & 0.22 & 5.48 & 31.57 & 69.06 \\
\hline Total & 20 & & & & & & & & & \\
\hline
\end{tabular}

Note: GeR: Germination rate (\%), SR: Survival rate (\%), SL: Shoot length (cm), LR: Root length $(\mathrm{cm})$, GRoR: Relative growth rate (\%), SH: Seedling height (cm), DTF: Days to flowering, FR: Fertility rate (\%), TGW: Thousand-grains weight (g)

SOV: Source of variation

DF: Degree of freedom

$*, * *, * *$, significant at $0.05,0.01$ and 0.001 levels of probability, respectively 
(a)

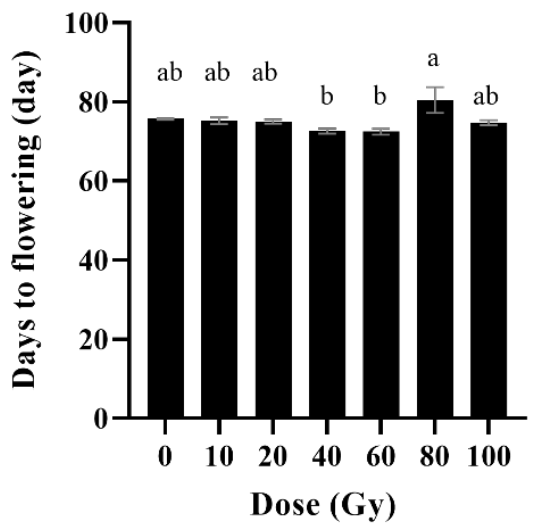

(b)

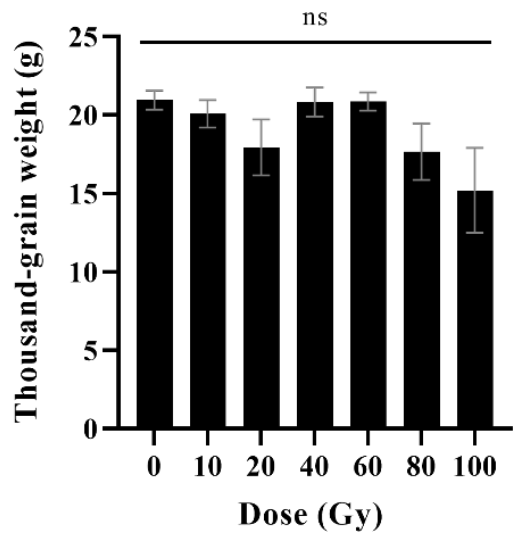

(c)

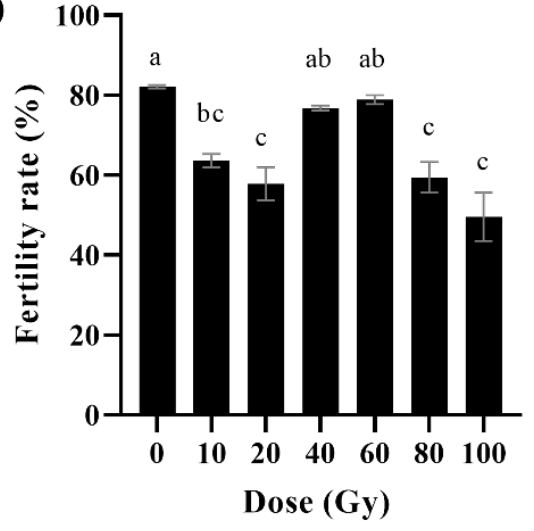

FIGURE 5. Morpho-agronomical traits of $\mathrm{M}_{1}$ individuals at different irradiation dose for days of flowering (a), 1000-grain weight (b) and fertility rate (c)

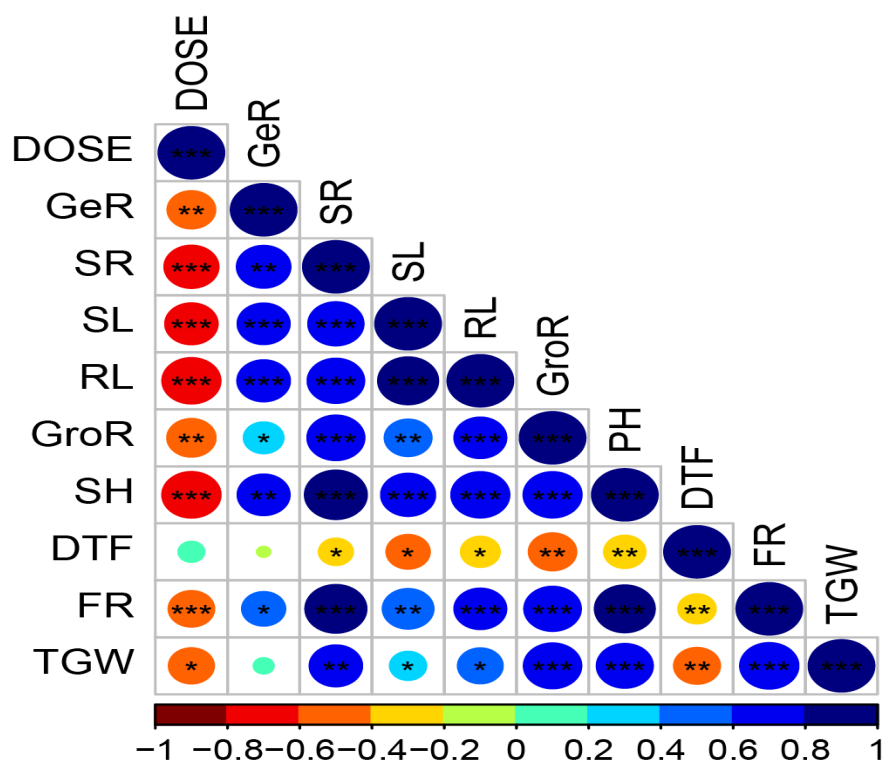

FIGURE 6. Graphical correlation matrix showing the relationship among traits and doses. $* * *$ and $* * *$ indicate significant at $0.05,0.01$ and 0.001 levels of probability, respectively 


\section{CORRELATION}

The coefficient of correlation among different phenotypic characters from the experiment is presented in Figure 6. All traits were significantly negatively correlated with the DOSE except for DTF $(r=0.15 ; p>0.05)$. This result indicates that increase in dose may reduce GeR, SR, SL, RL, GRoR, SH, TGW, and FR. The same results were also observed in other studies (Hidema et al. 2003; Hussien et al. 2020; Ling et al. 2013; Mamun et al. 2013; Preuss $\&$ Britt 2003; Tanaka et al. 2002). In contrast, SR was significantly positively correlated with all the traits except DTF $(r=-0.26 ; p>0.05)$ (Figure 6$)$. The highest positive correlation was between SR and SH $(r=0.89)$, and followed by between SR and FR $(r=0.86)$.

\section{CONCLUSION}

Generally, almost similar patterns of biological response towards carbon-ion beam irradiation were observed in all the traits except for DTF. The promising mutant lines of the progenies were detected at 40 and $60 \mathrm{~Gy}$ as they showed significant differences compared to other treatments (except for control) for GeR, SR, SL, RL, GRoR, SH, DTF and FR. Based on the results obtained in this study, the optimum dose range for carbon-ion beam irradiation for MR219-PL-5 was between 40 and $60 \mathrm{~Gy}$. This indicates that seeds irradiated within these two doses might have a greater chance of producing mutation with less radiation damage. Further studies using the advance mutant populations will help to identify potential mutant lines and determine the mutational regions as well as to understand the inheritance of each trait of interest from one generation to the next.

\section{ACKNOWLEDGEMENTS}

This study was funded by Universiti Kebangsaan Malaysia (UKM) under Research University Grant DCP2017-004/2 and GP-2019-K017409. The research facilities were provided by UKM and Nuklear Malaysia. Special thanks to Dr. Yoshihiro Hase from National Institutes for Quantum and Radiological Science and Technology (QST) for his contribution to the project.

\section{REFERENCES}

Abe, T., Kazama, Y., Ichida, H., Hayashi, Y., Ryuto, H. \& Fukunishi, N. 2007. Plant breeding using the ion beam irradiation in RIKEN. In Proceedings of the 18th International Conference on Cyclotrons and Their Applications CYCLOTRONS 2007. Saitama, Japan. pp. 222-224.
Awan, M.A. \& Bari, G. 1979. Mutagenic effects of fast neutrons and gamma rays in rice. Nucleus 16(1/2): 33-38.

Department of Agriculture Malaysia (DoA). 2018. Maklumat pertanian - aktiviti dan sumber. http://www.doa.gov.my/ index.php/pages/view/623. Accessed on 20 October 2020.

Gowthami, R., Vanniarajan, C., Souframanien, J. \& Pillai, A.M. 2017. Comparison of radiosensitivity of two rice (Oryza sativa L.) varieties to gamma rays and electron beam in $\mathrm{M}_{1}$ generation. Electronic Journal of Plant Breeding 8(3): 732-741.

Gregory, W.C. 1972. Manual on mutation breeding. Journal of Nuclear Energy 26(8): 443-444.

Hidema, J., Yamoto, M., Kumagai, T., Hase, K., Sakamoto, A. \& Tanaka, A. 2003. Biological effects of carbon ion on rice (Oryza sativa L.). Review-Japan Atomic Energy Research Institute 2003-033: 85-87.

Hussein, S., Harun, A.R., Simoli, J.M.A., Wahab, M.R.A., Salleh, S., Ahmad, F., Hoe, P.C.K., Rahman, S.A.A., Ahmad NAzrul, A.W., Nordin, L., Tanaka, A., Kiong, A.L.P., Yian, K.R., Yusop, M.R., Ilyani, A., Kogeethavani, R., Hase, Y., Koike, A., Noorman Affendi, M., Kamaruzaman, R., Hassan, N.A., Shamsudin, N.A.A. \& Hashim, N.M. 2020. Mutation breeding of rice for sustainable agriculture in Malaysia. In Mutation Breeding of Rice for Sustainable Agriculture Mutation Breeding Project Forum for Nuclear Cooperation in Asia (FNCA). Takasaki Advanced Radiation Research Institute, Japan. pp. 30-58.

Ibrahim, R., Harun, A.R., Hussien, S., Mat Zin, A., Othman, S., Mahmud, M., Yusof, M.R., Nahar, S.H.M., Kamaruddin, Z.S. \& Ana Ling, P.K. 2013. Application of mutation techniques and biotechnology for minimal water requirement and improvement of amylose content in rice. In FNCA Mutation Breeding Project. Takasaki Advanced Radiation Research Institute, Japan. pp. 46-59.

Ikmal, A.M., Noraziyah, A.A.S., Ellina, Z.P.D., Tuan Nur Aqlili Riana, T.A., Amira, I., Wickneswari, R. \& Aishah, Z.S. 2020. Genotype-by-environment interaction and stability analysis of $q D T Y$ s pyramided rice (Oryza sativa) lines under waterlimited environments. International Journal of Agriculture and Biology 24(6): 1835-1844.

Ikmal, A.M. Nurasyikin, N., Tuan Nur Aqlili Riana, T.A., Ellina, Z.P.D., Wickneswari, R. \& Noraziyah, A.A.S. 2019. Drought yield QTL $(q D T Y)$ with consistent effects on morphological and agronomical traits of two populations of new rice (Oryza sativa) lines. Plants 8(6): 186.

Ikmal, A.M., Nurasyikin, Z., Kumar, A. \& Noraziyah, A.A.S. 2018. Evaluation of morpho-physiological traits of MRQ74 pyramided lines with drought yield QTLs. Euphytica 214(6): 98.

Jones, H.E., West, H.M., Chamberlain, P.M., Parekh, N.R., Beresford, N.A. \& Crout, N.M.J. 2004. Effects of gamma irradiation on Holcus lanatus (Yorkshire fog grass) and associated soil microorganisms. Journal of Environmental Radioactive 74(1-3): 57-71. 
Kalimullah, M., Gaikwad, J.U., Thomas, S., Sarma, A. \& Vidyasagar, P.B. 2003. Assessment of ${ }^{1} \mathrm{H}$ heavy ion irradiation induced effects in the development of rice (Oryza sativa L.) seedlings. Plant Science 165(3): 447-454.

Khadimi, A.A., Alhasnawi, A.N., Isahak, A., Ashraf, M.F., Mohamad, A., Yusoff, W.M.W. \& Radziah, M.Z. 2016. Gamma radiosensitivity study on MRQ74 and MR269, two elite varieties of rice (Oryza sativa L.). Life Science Journal 13(2): 86-91.

Kim, J.H., Baek, M.H., Chung, B.Y., Wi, S.G. \& Kim, J.S. 2004. Alterations in the photosynthetic pigments and antioxidant machineries of red pepper (Capsicum annuиm L.) seedlings from gamma irradiated seeds. Journal of Plant Biology 47(2): 314-321.

Ling, A.P.K., Ung, Y.C., Hussein, S., Harun, A.R., Tanaka, A. \& Yoshihiro, H. 2013. Morphological and biochemical responses of Oryza sativa L. (cultivar MR219) to ion beam irradiation. Journal of Zhejiang University Science B 14(12): 1132-1143.

Long, S.P., Zhu, X.G., Naidu, S.L. \& Ort, D.R. 2006. Can improvement in photosynthesis increase crop yields. Plant Cell Environmental 29(3): 315-330.

Luo, J., Hu, P.S., Tang, S.Q., Jiao, G.A. \& Shao, G.N. 2013. Mutation breeding project: Sub-project on composition or quality in rice China, achievement sub-project on composition or quality in rice (2007-2012), mutation breeding project, forum for Nuclear Cooperation in Asia (FNCA), FNCA/ MEXT Technical Material, Japan. pp. 11-20. http://www. fnca.mext.go.jp/english/mb/rice/e rice.html.

Magori, S., Tanaka, A. \& Kawaguchi, M. 2010. Induced mutation. In The Handbook of Plant Mutation Screening, edited by Kahl, G. \& Meksen, K. New York: John Wiley \& Sons. pp. 1-16.

Mamun, A.N.K., Azad, A.K., Kabir, M.H., Roy, P.K., Islam, M.R., Jahan, M.T., Azam, M.A., Hakim, M.L. \& Ahmed, G. 2013. High yielding mutants with shorter life cycle selected in rice irradiated with carbon ion beam. In Mutation Breeding of Rice for Sustainable Agriculture Mutation Breeding Project Forum for Nuclear Cooperation in Asia (FNCA). Takasaki Advanced Radiation Research Institute, Japan. pp. 2-10.

Myhill, R.R. \& Konzak, C.F. 1967. A new technique for culturing and measuring barley seedlings. Crop Science 7(3): 275-277.

Oladosu, Y., Rafii, M.Y., Abdullah, N., Abdul Malek, M., Rahim, H.A., Hussin, G., Abdul Latif, M. \& Kareem, I. 2014. Genetic variability and selection criteria in rice mutant lines as a revealed by quantitative traits. Scientific World Journal 2014: 190531.

Preuss, S.B. \& Britt, A.B. 2003. A DNA-damage induced cell cycle checkpoint in Arabidopsis. Genetics 164(1): 323334.

Saweho, M.F., Purwanto, E. \& Yunus, A. 2019. The shortstemmed selection of M4 generation of Mentik Susu rice mutants as irradiation result with 200 gray gamma rays. Earth and Environmental Science 250(1): 012034.
Shamsudin, N.A.A., Swamy, B.P.M., Ratnam, W., Cruz, M.T.S., Sandhu, N., Raman, A.K. \& Kumar, A. 2016. Pyramiding of drought yield QTLs into a high-quality Malaysian rice cultivar MRQ74 improves yield under reproductive stage drought. Rice 9(1): 1-13.

Sjahril, R., Riadi, M., Rafiuddin, Sato, T., Toriyama, K., Abe, T. \& Trisnawaty, A.R. 2018. Effect of heavy ion beam irradiation on germination of local Toraja rice seed $\left(\mathrm{M}_{1}-\mathrm{M}_{2}\right)$ mutant generation. Conference Series: Earth and Environmental Science 157(1): 012046.

Tanaka, A., Nozawa, S., Hase, Y., Narumi, I., Ishikawa, H. \& Koike, A. 2010. Ion beam irradiation with rice seeds for the mutation breeding project of the forum for nuclear cooperation in Asia (FNCA). In FNCA Mutation Breeding Project Takasaki Advanced Radiation Research Institute, Japan. p. 61.

Tanaka, A., Kobayashi, Y., Hase, Y. \& Watanabe, H. 2002. Positional effect of cell inactivation on root gravitropism using heavy ion microbeams. Journal of Experimental Botany 53(369): 683-687.

Tanaka, A., Kawano, K. \& Yamaguchi, J. 1966. Photosynthesis, respiration and plant type of the tropical rice plant. International Rice Research Institute - Technology Bulletin 7: 45-46.

Ulukapi, K. \& Nasircilar, A.G. 2018. Induced mutation: Creating genetic diversity in plants. In Genetic Diversity in Plant Species - Characterization and Conservation, edited by ElEsawi, M.A. Intech Open. pp. 1-15.

Vazquez-Tello, A., Uozumi, T., Hidaka, M., Kobayashi, Y. \& Wanatabe, H. 2005. Effect of ${ }^{12} \mathrm{C}_{+5}$ ion beam irradiation on cell viability and plant regeneration in callus, protoplasts and cell suspensions of Lavatera thuringiaca. Plant Cell Reproduction 16(1-2): 46-49.

Yamaguchi, H. 2013. Characteristics of ion beams as mutagens for mutation breeding in rice and chrysanthemums - Review. Japan Agriculture Research Quarterly Journal 47(4): 339346.

Yamaguchi, H. 2011. Mutational Breeding with Ion and Gamma Rays. Japan: Chiba University Press.

Yamaguchi, H., Hase, Y., Tanaka, A., Shikazono, N., Degi, K., Shimizu, A. \& Morishita, T. 2009. Mutagenic effect of ion beam irradiation on rice. Breeding Science 59(2): 169177.

Yasmine, F., Ullah, M.A., Ahmad, F., Rahman, M.A. \& Harun, A.R. 2019. Effect of chronic gamma radiation on three rice varieties. Jurnal Sains Nuklear Malaysia 31(1): 1-10.

Zheng, Y., Li, S., Huang, J., Fu, H., Zhou, L., Furusawa, Y. \& Shu, Q. 2020. Mutagenic effects of three ion beams on rice and identification of heritable mutations by whole genome sequencing. Plants 9(55): 551.

Asrapil Waitul Fifika, Asmuni Mohd Ikmal \& Abd Aziz Shamsudin Noraziyah*

Department of Biological Sciences and Biotechnology

Faculty of Science and Technology

Universiti Kebangsaan Malaysia

43600 UKM Bangi, Selangor Darul Ehsan

Malaysia 
Ahmad Faiz, Harun Abdul Rahim \& Hussein Sobri Agrotechnology and Biosciences Division

Malaysian Nuclear Agency Bangi

43000 Kajang, Selangor Darul Ehsan

Malaysia
Hasan Nor'aishah

Faculty of Applied Sciences

Universiti Teknologi MARA

Cawangan Negeri Sembilan Kampus Kuala Pilah

Negeri Sembilan, Malaysia

*Corresponding author; email: nora_aziz@ukm.edu.my

Received: 26 October 2020

Accepted: 14 April 2021 